\title{
DNA markers as a tool for genetic traceability of primary product in agri-food chains
}

\author{
Daria Scarano, ${ }^{1}$ Cinzia Montemurro, ${ }^{2}$ Giandomenico Corrado, ${ }^{1}$ Antonio Blanco, ${ }^{2}$ Rosa Rao ${ }^{1}$ \\ 'Dipartimento di Scienze del Suolo, della Pianta, dell'Ambiente e delle Produzioni Animali, \\ Università di Napoli Federico II, Portici (NA); \\ 2Dipartimento di Biologia e Chimica Agro-forestale ed Ambientale, sezione di Genetica e \\ Miglioramento genetico, Università di Bari Aldo Moro, Bari, Italy
}

\begin{abstract}
The agri-food components of the Made in Italy are well known all over the world, therefore they may significantly contribute to the Italian economy. However, also owing to a large number of cases of improper labelling, the Italian agro-food industry faces an ever-increasing competition. For this reason, there is a decline of consumers' confidence towards food production systems and safety controls. To prevent erroneous classification of products and to protect consumers from false instore information, it is important to develop and validate techniques that are able to detect mislabelling at any stage of the food-chain. This paper describes some examples of genetic traceability of primary products in some important plant food chains such as durum wheat, olive and tomato, based on DNA analysis both of raw material and of processed food (pasta, olive oil, and peeled tomato).
\end{abstract}

\section{Introduction}

In the agro-food world market the label Made in Italy is certainly very popular, but recent data show a decrease of the Italian performance on international markets (http://www.oecd.org/), probably due to the high competition of global market systems. Italian agro-food provides an important contribution to the National economy: a variety of

\footnotetext{
Correspondence: Dr. Rosa Rao, Dipartimento di Scienze del Suolo, della Pianta, dell'Ambiente e delle Produzioni Animali, Università di Napoli Federico II, via Università 100, 80055 Portici (NA), Italy.

Tel. +39.081.2539204 - Fax: +39.081.2539481. E-mail: rosa.rao@unina.it

Key words: molecular markers, SSR, AFLP, tomato, olive oil, durum wheat pasta.

Received for publication: 2 May 2012.

Accepted for publication: 24 August 2012.

(C) Copyright D. Scarano et al., 2012

Licensee PAGEPress, Italy

Italian Journal of Agronomy 2012; 7:e45

doi:10.4081/ija.2012.e45

This article is distributed under the terms of the Creative Commons Attribution Noncommercial License (by-nc 3.0) which permits any noncommercial use, distribution, and reproduction in any medium, provided the original author(s) and source are credited.
}

typical products (i.e. wines, pasta, sauces, oils and gastronomic preparations), that have quality labels [i.e. Protected Designation of Origin (PDO) or Protected Geographical Indication (PGI)] and belong to consolidated cultural and culinary traditions (tomato San Marzano, apple Annurca, apricot of the Vesuvio, olive oil Terra di Bari, Altamura bread and many others) are popular abroad and give important contributions to the export of Italian agro-products. Currently, the number of food frauds is increasing and recent data suggest that the Italian products are the most affected, because of their good quality and well known fame (http://www.mdc.it/it/3715.html).

Markets globalization largely affects supply chain networks that, in consequence, became extremely complex to control. For example, although Italian agriculture has a long standing tradition in tomato production, presently the processed tomatoes are largely imported from China (42\% of total imports in 2010; www.coldiretti.it). At the same time, there is a growing decline of consumers' confidence for food production systems and controls as well as for the credence attributes such as healthy and safe food chains. This is due to the progressive loss of contact between consumers and the food production systems and it is boosted by recent food crises: the cases of the Bovine Spongiform Encephalopathy (BSE) and of the contamination with dioxin or with mercury of animal feed and fish respectively. For these reasons there is an increasing demand for identification and labelling of food products (Ammendrup and Fussel, 2001; Caporale et al., 2001; Carcea et al., 2009; Wen et al., 2010).

In this context, technologies able to trace primary products processed in food chains represent a key issue that is receiving growing attention both from producers and consumers for the relevant contributions they may offer in respect to fraud and mislabelling reports and their connections with the possibility to track the food geographic origin.

\section{Traceability}

The traceability is the ability to trace and follow a food, feed, an animal or substance intended to become part of a food or feed, through all stages of production, processing and distribution (EU regulation No. 178/2002). This definition is necessarily broad because food and feed are complex matrixes and traceability is a tool that should allow to track them, from row materials (e.g., plant cultivars) to final processed products and beyond, up to market distribution and consumers. As a consequence, no traceability system is complete. Therefore different systems should be integrated to satisfy different requirements.

The important parameters that characterize a traceability system are breadth, depth, precision and running costs. Breadth relates to the 
amount of available information which should include key attributes (for example product or process characteristics). Depth describes how far, back or forward inside the food netchain, the system is able to capture the relevant information (for example, a traceability system for cultivar authentication should be able to authenticate the genetic material both back to cultivation and forward to processed food). Precision reflects the capability to provide information in a particular step of a food chain (e.g., in cultivar authentication precision is the ability to identify contaminating genetic material). Running costs, that include the resources to set-up and run the system, should be in a range that would incentivize industries to activate traceability systems from which they could receive consistent benefits as they can improve the appropriate use and reliability of information, effectiveness and productivity of the organization.

The tracking method involves monitoring of stuff flow from the raw material to final sale. This can be essentially done by the manufacturer through a process of self-certification to be released, for example, after the measurement of specific physicochemical parameters that are supposed to be almost invariable during transition from raw material to final product. A company that is able to follow the entity flow and to monitor at any time raw material, semi-processed or processed products that are within the limits of its own responsibility, is a company able to streamline identification processes, to individuate causes of errors, to monitor the efficiency of each stage and of the overall process. In addition, the possibility to verify the geographic origin of the primary product increases the value of quality certification (such as PGI, PD0) (Rao et al., 2009a), supporting the development of local economies through the commercialization of typical food products.

For all the above mentioned considerations, we believe that the development of a highly comprehensive and efficient traceability system requires an integrated interdisciplinary approach of the different expertises active in the agro-food sciences, that allow to study the system from different points of views.

\section{Genetic traceability}

Genetic traceability, based on DNA analysis, refers to the ability of a system to identify the species or genotypes of food stuff components. This system is depth and precise as may allow to identify and trace food components along the netchain. For example it has been demonstrated that the DNA sequence of a single mitochondrial gene (in animals) or chloroplast gene (in plants) differs among species but is very much alike in individuals of the same species (Waugh, 2007; Lahaye et al., 2008). As a consequence, the nucleotide sequence polymorphism of these genes could be used as a barcode, theoretically able to identify every species (http://barcoding.si.edu/).

DNA barcoding in animals is typically based on the mitochondrial gene cox 1 sequence variations available in comprehensive databases. The system is presently routinely used for animal species identification and has successfully contributed towards food authentication. Species discrimination has been very successful in seafood industry (Nicolè $e t$ al., 2012) allowing to highlight frauds caused by substitution of expensive fish species by cheap one (Eugene et al., 2008; Filonzi et al., 2010) as well as in meat industry (Chen et al., 2010). In plants a number of different chloroplast genes have been proposed, but there is not yet any universally accepted barcode (Lahaye et al., 2008). Nevertheless DNA barcoding proved effective in tracing out olive oil adulteration by canola and sunflower oil, not always easy to identify by using fatty acid analysis (Kumar et al., 2011).

For many plant species, the market price of an edible product is largely dependent on the cultivated varieties. Compared to animal samples, the correct identification of the cultivated plant variety requires a deeper level of genetic information as it often relies on intra-species genetic variability. The analysis of such variability at molecular level represents a reliable tool to identify DNA fingerprints of cultivated varieties. Application of DNA fingerprint in plant food traceability allows the authentication of cultivars in commercial edible products. DNA fingerprint may be determined through different types of molecular markers; the most commonly used markers are:

RFLP, Restriction Fragment Length Polymorphism (Van Ooijen et al., 1994; Sandbrink et al., 1995; Smulders et al., 1997);

RAPD, Randomly Amplified Polymorphic DNA (Stevens et al., 1995; Grandillo and Tanksley, 1996);

AFLP, Amplified Fragment Length polymorphism (Rao et al., 2009b; Rony et al., 2009);

VNTR, Variable Number of Tandem Repeat, or minisatellites (Andreakis et al., 2004);

SSR, Simple Sequence Repeat, or microsatellites (Smulders et al., 1997; He et al., 2003, Corrado et al., 2009);

CAPS, Cleaved Amplified Polymorphic Sequence (Yang et al., 2004; Caramante et al., 2009);

COS, Conserved Ortholog Set (Fulton et al., 2002; Van Deynze et al., 2007; Labate et al., 2009);

SNP, Single Nucleotide Polymorphism (Labate and Baldo, 2005); In/Del, Insertion Deletion (Yang et al., 2004).

They are all characterized by significant discrimination power although technical feasibility and running costs may differ consistently. The direct identification of polymorphism at the DNA level provides a powerful tool for the authentication of row and processed food components as a pool of DNA sequences may univocally identify a genotype.

The application of DNA fingerprint to the identification, characterization and traceability of plant species and cultivars in food chains has been demonstrated in different studies. For example, Terzi and coworkers (2004) highlighted the possibility to identify wheat species used for pasta production through AFLP markers. Similarly, SSR polymorphism was able to discriminate apple varieties and to authenticate the cultivar Annurca in processed food such as apple purée and nectar (Melchiade et al., 2007).

\section{Tomato traceability through Simple Sequence Repeat allelic profiles}

As mentioned for animal food chains, also for plant food chains it happens that, due to economic interests, premium varieties are replaced with varieties of lower quality. For example, San Marzano, a traditional tomato local variety with DP0, is frequently substituted with different cultivars with similar fruit shape and size (Scarano et al., 2011). Recently, it has been reported that SSR alleles are stable in the tomato food chain (Caramante et al., 2010; Turci et al., 2010) and that SSR allelic profiles successfully trace tomato cultivars in peeled, diced and cherry canned tomatoes (Caramante et al., 2010). Moreover, it was shown that SSR fingerprinting is useful to evidence erroneous labelling of processed tomato, possible consequence of the failure of the internal traceability system in establishing correct associations between registration numbers and genetic identity of samples entering and exiting the industrial process (Caramante et al., 2010).

\section{Olive oils traceability through DNA marker profiles}

Olive (Olea europea $\mathrm{L}$.) is one of the oldest and most important crops 
in the Mediterranean area. The database of the olive germplasm (http://www.oleadb.it) contains information on 5435 accessions, stored in more than 100 different collections. About two-thirds of the varieties are present in the Southern European countries. Unfortunately, the characterization of olive germplasm resources is complicated by the very large number of available accessions, not always properly classified, that originate several cases of synonymy or homonymy (Bartolini et al., 2005). In this scenario the evaluation of olive molecular diversity is particularly important both for discrimination of olive varieties and clones and for the valorisation and protection of high quality extravirgin olive oils (Doveri et al., 2008; Baldoni et al., 2009; Rao et al., 2009b; Rony et al., 2009).

Cultivar traceability in extra-virgin olive oils has been demonstrated by a number of papers (Busconi et al., 2003; Pasqualone et al., 2004; Pafundo et al., 2005; Muzzalupo et al., 2007; Pasqualone et al., 2007a; Consolandi et al., 2008; Montemurro et al., 2008; Alba et al., 2009) and recently the possibility to identify the varieties included in simple olive oil blends was also reported (Pasqualone et al., 2007b; Corrado et al., 2011). In addition, Montemurro and colleagues (2008) demonstrated the high discrimination power of AFLP markers in olive oils identification. These authors show that one AFLP primer combination, revealing 29 polymorphic bands, identifies ten extra virgin olive oils prepared in the laboratory from ten different Italian cultivars. The extension of this analysis to commercial monovarietal olive oils would validate the powerfulness of AFLP markers application in olive food industry.

The improvement of DNA-based methodology to authenticate varieties used for olive oil production represent an important requisite to certify and protect quality labels, against fraud and mislabelling.

\section{Quantification of soft wheat adulteration in durum wheat-based foodstuffs by real-time PCR}

Pasta is a traditional Italian product, made of durum wheat (Triticum turgidum L. Thell. subsp. turgidum convar. durum Desf. MK.). Currently, Italian legislation interdicts the production of pasta containing soft wheat (Triticum aestivum L. Thell. subsp. vulgare Vill. MK.). Only a maximum of $3 \%$ of $T$. aestivum can be tolerated to account for cross contamination during the agricultural process (DPR Reg. 187/2001). However, Italy allows import-export of pasta totally or partially prepared using T. aestivum. It is obvious that the composition of such product should be clearly labelled (Sonnante et al., 2009). Consequently, there is a strong interest in the development of molecular methods able to detect soft wheat in pasta.

Monitoring the presence of soft wheat in durum wheat semolina and pasta preparations has always been of interest for Italian food industry and analytical methods used to discriminate between the two species were previously based on the analyses of protein fractions (Cantagalli, 1969; Garcia-Faure et al., 1969; Stevenson et al., 1994). However, proteins have a reduced stability in comparison with nucleic acids especially in processed food as bakery products that are exposed to high temperature. Recently, a new method based on DNA screening for sequences localized in the D-genome, has been developed (Bryan et al., 1998; Alary et al., 2002; Arlorio et al., 2003; Terzi et al., 2003; Pasqualone et al., 2007c; Prins et al., 2010). A microsatellite region mapping exclusively on the wheat D-genome proved to be able to detect and quantify soft wheat in durum wheat semolina and in some typical breads made in Southern Italy like Pane di Altamura and Pane di Matera, awarded with PDO and PGI marks, respectively that have to be prepared exclusively employing durum wheat (Pasqualone et al. 2007c; Sonnante et al., 2009) .

\section{Conclusions}

Validation of product quality, and safety in agri-food sectors has become a priority. To meet this requirement the development of a highly comprehensive and efficient traceability system, that integrates multidisciplinary approaches, is highly desirable.

Genetic traceability based on DNA markers offers a valuable contribution for the identification of genetic material along the production chains, also because DNA is a molecular label difficult to remove or alter. It may restore consumers' confidence in respect of possible frauds and protect individual food choices as it can partially verify the information upon food labels.

\section{References}

Alary R, Serin A, Duviau MP, Joudrier P, Gautier MF, 2002. Quantification of common wheat adulteration of durum wheat pasta using real-time quantitative polymerase chain-reaction (PCR). Cereal Chem. 79:553-558.

Alba V, Sabetta W, Blanco A, Pasqualone A, Montemurro C, 2009. Microsatellite markers to identify specific alleles in DNA extracted from monovarietal virgin olive oils. Eur. Food Res. Technol. 229:375-82.

Ammendrup S, Fussel AE, 2001. Legislative requirements for the identification and traceability of farm animals within the European Union. Rev. Sci. Tech. OIE 20:437-444.

Andreakis N, Giordano I, Pentangelo A, Fogliano V, Graziani G, Monti LM, Rao R, 2004. DNA fingerprinting and quality traits of Corbarino cherry-like tomato landraces. J. Agr. Food. Chem. 52:3366-3377.

Arlorio M, Coisson J, Cereti E, Travaglia F, Papasso M, Martelli A, 2003. Polymerase chain reaction (PCR) of puroindoline b and riboso$\mathrm{mal} /$ puroindoline $\mathrm{b}$ multiplex PCR for the detection of common wheat (Triticum aestivum) in Italian pasta. Eur. Food Res. Technol. 216:253-258.

Baldoni L, Cultrera NG, Mariotti R, Ricciolini C, Arcioni S, Vendramin GG, Buonamici A, Porceddu A, Sarri V, Ojeda MA, Trujillo I, Rallo L, Belaj A, Perri E, Salimonti A, Muzzalupo I, Casagrande A, Lain 0, Messina R, Testolin R, 2009. A consensus list of microsatellite markers for olive genotyping. Mol. Breeding 24:213-231.

Bartolini G, Prevost G, Messeri C, Carignani G, 2005. Olive germplasm: cultivars and world-wide collections. Available from: http://apps3.fao.org/wiews/olive/oliv.jsp

Busconi M, Foroni C, Corradi M, Bongiorni C, Cattapan F, Foghera C, 2003. DNA extraction from olive oil and its use in the identification of the production cultivar. Food Chem. 83:127-134.

Bryan GJ, Dixon A, Gale MD, Wiseman G, 1998. A PCR-based method for the detection of hexaploid bread wheat adulteration of durum wheat and pasta. J. Cereal Sci. 28:135-145.

Cantagalli P, 1969. Control of the adulteration of durum wheat macaroni by the immunodiffusion method. Ann. Ist. Super. Sanità 5:414416.

Caporale V, Giovannini A, Francesco C, Calistri P, 2001. The importance of traceability of animals and animal products in epidemiology. Rev. Sci. Tech. OIE 20:372-378.

Caramante M, Corrado G, Monti LM, Rao R. 2010. Simple Sequence Repeats are able to trace tomato cultivars in tomato food chains. Food Control 22:549-554.

Caramante M, Rao R, Monti LM, Corrado G, 2009. Discrimination of 'San Marzano' accessions: A comparison of minisatellite, CAPS and SSR markers in relation to morphological traits. Sci. Hortic. 120:560-564.

Carcea M, Brereton P, Hsu R, Kelly S, Marmiroli N, Melini F, Soukoulis 
C, Wenping D, 2009. Food authenticity assessment: ensuring compliance with food legislation and traceability requirements. In: R. Poms and S. Cauvein (eds.) Quality Assurance and Safety of Crops \& Foods. ICC and Blackwell Publ. Ltd., pp 93-100.

Chen SY, Liu YP, Yao YG, 2010. Species authentication of commercial beef jerky based on PCR-RFLP analysis of the mitochondrial $12 \mathrm{~S}$ rRNA gene. J Genet Genomics 37:763-769.

Consolandi C, Palmieri L, Doveri S, Maestri E, Marmiroli N, Reale S, Lee D, Baldoni L, Tosti N, Severgnini M, De Bellis G, Castiglioni B, 2007. Olive variety identification by ligation detection reaction in a universal array format. J. Biotech. 129:565-574.

Corrado G, Imperato A, La Mura M, Perri E, Rao R, 2011. Genetic diversity among olive varieties of southern italy and the traceability of olive oil using SSR markers. J. Hortic. Sci. Biotech. 86:461-466.

Corrado G, La Mura M, Ambrosino 0, Pugliano G, Varricchio P, Rao R, 2009. Relationships of Campanian olive cultivars: comparative analysis of molecular and phenotypic data. Genome 52:692-700.

Doveri S, Sabino Gil F, Díaz A, Reale S, Busconi M, da Câmara Machado A, Martín A, Fogher C, Donini P, Lee D, 2008. Standardization of a set of microsatellite markers for use in cultivar identification studies in olive (Olea europaea L.). Sci. Hortic. 116:367-373.

Eugene H, Wong K, Hanner RH, 2008. DNA barcoding detects market substitution in North American seafood. Food Res. Int. 41:828-837.

Filonzi L, Chiesa S, Vaghi M, Nonnis Marzano F, 2010. Molecular barcoding reveals mislabelling of commercial fish products in Italy. Food Res. Int. 43:1383-1388.

Fulton TM, van der Hoeven R, Eannetta NT, Tanksley SD, 2002. Identification, analysis, and utilization of conserved ortholog set markers for comparative genomics in higher plants. Plant Cell 14:1457-1467.

Garcia-Faure R, Merck-Luengo JG, Garcia-Olmedo F, 1969. Detection of flour or farina from Triticum aestivum in macaroni by starch gel electrophoresis of water-soluble proteins. Cereal Chem. 46:621625.

Kumar S, Kahlon TS, Chaudhary S, 2011. A rapid screening for adulterants in olive oil using DNA barcodes. Food Chem. 127:1335-1341.

Grandillo S, Tanksley SD, 1996. Genetic analysis of RFLPs, GATA microsatellites and RAPDs in a cross between L. esculentum and L. pimpinellifolium. Theor. Appl. Genet. 92:957-965.

He C, Poysa V, Yu K, 2003. Development and characterization of simple sequence repeat (SSR) markers and their use in determining relationships among Lycopersicon esculentum cultivars. Theor. Appl. Genet 106:363-373.

Labate JA, Baldo AM, 2005. Tomato SNP discovery by EST mining and resequencing. Mol. Breeding 16:343-349.

Labate JA, Robertson LD, Wu F, Tanksley SD, Baldo AM, 2009. EST, COSII, and arbitrary gene markers give similar estimates of nucleotide diversity in cultivated tomato (Solanum lycopersicum L.). Theor. Appl. Genet. 118:1005-1014.

Lahaye R, van der Bank M, Bogarin D, Warner J, Pupulin F, Gigot G, Maurin O, Duthoit S, Barraclough T.G, Savolainen V. 2008. DNA barcoding the floras of biodiversity hotspots. P. Natl. Acad. Sci. USA 105:2923-2928.

Melchiade D, Foroni I, Corrado G, Santangelo I, Rao R, 2007. Authentication of the 'Annurca' apple in agro-food chain by amplification of microsatellites loci. Food Biotech. 21:33-43.

Montemurro C, Pasqualone A, Simeone R, Sabetta W, Blanco A, 2008. AFLP molecular markers to identify virgin olive oils from single Italian cultivars. Eur. Food Res. Technol. 226:1439-1444.

Muzzalupo I, Pellegrino M, Perri E, 2007. Detection of DNA in virgin olive oils extracted from destoned fruits. Eur. Food Res. Technol. 224:469-475.

Nicolè S, Negrisolo E, Eccher G, Mantovani R, Patarnello T, Erickson DL, Kress WJ, Barcaccia G, 2012. DNA barcoding as a reliable method for the authentication of commercial Seafood Products. Food Technol. Biotech. (In press).

Pafundo S, Agrimonti C, Marmiroli N, 2005. Traceability of plant contribution in olive oil by Amplified Fragment Length Polymorphisms. J. Agric. Food Chem. 53:6995-7002.

Pasqualone A, Montemurro C, Caponio F, Blanco A, 2004. Identification of Virgin Olive Oil from Different Cultivars by Analysis of DNA Microsatellites. J. Agric. Food Chem. 52:1068-1071.

Pasqualone A, Montemurro C, Grinn-Gofron A, Sonnante G, Blanco A, 2007a. Detection of soft wheat in semolina and durum wheat bread by analysis of DNA microsatellites. J. Agric. Food Chem. 55:33123318.

Pasqualone A, Montemurro C, Summo C, Sabetta W, Caponio F, Blanco A, 2007b. Effectiveness of microsatellite DNA markers in checking the identity of Collina di Brindisi PDO Extra Virgin olive oil. J. Agric. Food Chem. 55:3857-3862.

Pasqualone A, Montemurro C, Summo C, Sabetta W, Caponio F, Blanco A, 2007c. Effectiveness of microsatellite DNA markers in checking the identity of protected designation of origin extra virgin olive oil. J. Agric. Food Chem. 55:3857-3862.

Prins TW, van Dijk JP, Van Hoef AMA, Voorhuijzen MM, Broeders S, Trapmann S, Seyfarth R, Pardigol A, Schoen CD, Aarts HJM, Kok EJ. 2010 Towards a multiplex cereal traceability tool using padlock probe ligation on genomic DNA. Food Chem. 118:966-973.

Rao R, Caramante M, Blanco A, Lanteri S, Lucchin M, Mazzucato A, 2009a. Innovazioni genetiche per l'identificazione e la protezione di prodotti tipici italiani. Ital. J. Agron. 3:95-101.

Rao R, La Mura M, Corrado G, Ambrosino 0, Foroni I, Perri E, Pugliano G, 2009b. Genetic diversity of olive cultivars using AFLP and morphological traits. J. Hortic. Sci. Biotech. 84:261-266.

Rony C, Baalbaki R, Kalaitzis P, Talhouk SN, 2009. Molecular characterization of Lebanese olive germplasm. Tree Genet. Genomes 5:109115.

Sandbrink JM, Van Ooijen JW, Purimahua CC, Vrielink M, Verkerk R, Zabel P, Lindhout P, 1995. Localization of genes for bacterial canker resistance in Lycopersicon peruvianum using RFLPs. Theor. Appl. Genet. 95:444-450.

Scarano D, Corrado G, Caramante M, Rao R, 2011. SSR fingerprinting reveals mislabelling of commercial 'San Marzano' tomato products. Minerva Biotecnol. 23:42-44.

Smulders MJM, Bredemeijer G, Rus-Kortekaas W, Arens P, Vosman B, 1997. Use of short microsatellites from database sequences to generate polymorphisms among Lycopersicon esculentum cultivars and accessions of other Lycopersicon species. Theor. Appl. Genet. 97:264-272.

Sonnante G, Montemurro C, Morgese A, Sabetta W, Blanco A, Pasqualone A, 2009. DNA microsatellite region for a reliable quantification of soft wheat adulteration in durum wheat-based foodstuffs by Real-Time PCR. J. Agric. Food Chem. 57:10199-10204.

Stevens MR, Lamb EM, Rhoads DD, 1995. Mapping the Sw-5 locus for tomato spotted wilt virus resistance in tomatoes using RAPD and RFLP analyses. Theor. Appl. Genet. 90:451-456.

Stevenson A, McCarthy PK, Griffin M, 1994. Polyclonal antisera against unheated and heated common wheat specific gamma and omega gliadins for the detection and adulteration of durum wheat and durum wheat products with common wheats. Food Agric. Immunol. 6:435-442.

Terzi V, Malnati M, Barbanera M, Stanca AM, Faccioli P, 2003 Development of analytical systems based on real time PCR for Triticum species-specific detection and quantitation of bread wheat contamination in semolina and pasta. J. Cereal Sci. 38:8794.

Terzi V, Morcia C, Giovanardi D, D’Egidio MG, Stanca AM, Faccioli P, 2004. DNA-based analysis for authenticity assessment of monova- 
Wen J, Hu C, Zhang L, Luo P, Zhao Z, Fan S, Su T, 2010. The application

rietal pasta. Eur. Food Res. Technol. 219:428-431.

Turci M, Sardaro MLS, Visioli G, Maestri G, 2010. Evaluation of DNA extraction procedures for traceability of various tomato products. Food Control 21:143-149.

Van Deynze AE, Wilkins TA, Stoffel K, Lee M, Stelly D, Kozik A, 2007. A set of informative markers designed specifically for breeding cotton. XV PAG, San Diego, California, 657.

Van Ooijen JW, Sandbrink JM, Vrielink M, Verkerk R, Zabel P, Lindhout P, 1994. An RFLP linkage map of Lycopersicon peruvianum. Theor. Appl. Genet. 89:1007-1013. of PCR-RFLP and FINS for species identification used in sea cucumbers (Aspidochirotida: Stichopodidae) products from the market. Food Control 21:403-407.

Waugh J, 2007. DNA barcoding in animal species: progress, potential and pitfalls. BioEssays 29:188-197.

Yang W, Bai X, Kabelka E, Eaton C, Kamoun S, van der Knaap E, Francis DM, 2004. Discovery of single nucleotide polymorphisms in Lycopersicon esculentum by computer aided analysis of expressed sequence tags. Mol. Breeding 14:21-34. 